\title{
Heavy Metals Contamination of Soil in the Vicinity of Hawassa Industrial Zone, Ethiopia
}

\author{
${ }^{1 *}$ SAMUEL, B; ${ }^{1}$ SOLOMON, S; ${ }^{1}$ DANIEL, F ; ${ }^{1} \mathrm{ZINABU}, \mathrm{GM} ;{ }^{2} \mathrm{RIISE}, \mathrm{G}$ \\ ${ }^{1}$ Hawassa University, Department of Biology, Hawassa, Ethiopia. \\ ${ }^{2}$ Norwegian University of Life Sciences, Faculty of Environmental Sciences and Natural Resource Management, As, Norway. \\ *Corresponding Author Email: beksam10@gmail.com, Tel: +251913016302
}

\begin{abstract}
Industrial effluents, containing heavy metals, drain directly into downstream water sources within the Hawassa Industrial Zone. These, water sources are used for irrigation, drinking water and other domestic purposes. The load of pollutants, environmental risks and potential human impacts are generally, unknown for soil in Ethiopia. Therefore, the aim of this study was to determine the extent of heavy metal pollution of soil within the Hawassa Industrial Zone and to evaluate environmental impacts using contamination factor (CF), degree of contamination $\left(\mathrm{C}_{\mathrm{d}}\right)$, modified degree of contamination $\left(\mathrm{mC}_{\mathrm{d}}\right)$, ecological risk factor $\left(\mathrm{E}_{\mathrm{r}}\right)$, ecological risk index (ERI) and pollution load index (PLI) analyses. Seven heavy metals: $\mathrm{Cr}, \mathrm{Ni}, \mathrm{Cu}, \mathrm{Zn}, \mathrm{As}, \mathrm{Cd}$ and $\mathrm{Pb}$ were determined in soil samples from three different sites by inductively coupled plasma mass spectrometry (ICP-MS). Average concentration of metals decreased in the order of $\mathrm{Zn}>\mathrm{Cu}>\mathrm{Cr}>\mathrm{Ni}>\mathrm{Pb}>\mathrm{As}>\mathrm{Cd}$ consistent with the normal order of abundance in non-polluted soils. One way ANOVA revealed significant differences $(P<0.05)$ in the concentrations of $\mathrm{Cu}, \mathrm{As}, \mathrm{Cd}$ and $\mathrm{Pb}$ among the sampling sites. Pearson's correlation, principal component and cluster analyses revealed that heavy metals are originating from different sources. Within the industrial area, the CF increased in the order of $\mathrm{Pb}<\mathrm{Cd}<\mathrm{Zn}<\mathrm{As}<\mathrm{Cu}<\mathrm{Cr}<\mathrm{Ni}$. The result of $\mathrm{C}_{\mathrm{d}}$ revealed that there was considerable to very high contamination of the soil. The $\mathrm{mC}_{\mathrm{d}}$ index showed moderate contamination of the soils. The $\mathrm{E}_{\mathrm{r}}$ increased in the order of $\mathrm{Zn}<\mathrm{Cr}<\mathrm{Pb}<\mathrm{Cu}<\mathrm{Ni}<\mathrm{As}<\mathrm{Cd}$ and the result of the ERI value revealed considerable ecological risk for the soils. Overall, the study showed that the soils within the Hawassa Industrial Zone are highly contaminated with heavy metals. Therefore, regular monitoring of heavy metals concentration in soil and policy interventions with respect to waste disposal are recommended.
\end{abstract}

\section{DOI:https://dx.doi.org/10.4314/jasem.v24i8.21}

Copyright: Copyright (C) 2020 Samuel et al. This is an open access article distributed under the Creative Commons Attribution License (CCL), which permits unrestricted use, distribution, and reproduction in any medium, provided the original work is properly cited.

Dates: Received: 30 May 2020; Revised: 03 July 2020; Accepted: 05August 2020

Keywords: Heavy metals, potential ecological risks, pollution load index, soil

Soil pollution by heavy metals has become a severe global problem (Danica and Juraj, 2020; Fawen et al., 2020), especially for African countries like Ethiopia where waste disposal is a major problem. Although heavy metals occur naturally in soil, anthropogenic activities such as agriculture (fertilizers and pesticides application), urbanization, industrialization and mining significantly raises the levels of heavy metals. As a result of rapid industrialization and urbanization, the disposal of untreated and/or partially treated effluents from various industries, urban wastes, and the use of agrochemicals, the pollution level has reached alarming situation in Ethiopia with increasing metal levels and deterioration of agricultural soil quality (Benti et al., 2016; Ftsum and Abraha, 2018). At present, agricultural soils in Ethiopia are becoming increasingly polluted with heavy metals, especially, in urban centers. The dominant heavy metal pollutant sources in Ethiopian agricultural soils are irrigation with rivers/streams laden with industrial effluents and application of fertilizers and pesticides (Hintsa et al., 2016; Gebeyehu and Bayissa, 2020). Hawassa Industrial Zone consists of a cluster of industries (Moha Soft Drink, Brewery-BGI, Textile, etc) that discharge untreated and/or partially treated effluents directly into the nearby streams that the local community uses for different purposes such as irrigation, water supply to their cattle, and other domestic uses (Zinabu and Zerihun, 2002; Solomon et al., 2015). Although there are some studies (Hintsa et al., 2016; Ftsum and Abraha, 2018; Gebeyehu and Bayissa, 2020) on the concentration of heavy metals in soils in Ethiopia, there is no such study in Hawassa Industrial Zone. Therefore, the aim of this study was to determine the concentration of heavy metals in soil from Hawassa Industrial Zone and assess pollution of the soil using different environmental indices such as contamination factor (CF), degree of contamination $\left(\mathrm{C}_{\mathrm{d}}\right)$, modified degree of contamination $\left(\mathrm{mC}_{\mathrm{d}}\right)$, ecological risk factor $\left(\mathrm{E}_{\mathrm{r}}\right)$, ecological risk index $(\mathrm{ERI})$ 
and pollution load index (PLI) analyses. These environmental indices provide information on the potential impacts from soil pollution in the area.

\section{MATERIALS AND METHODS}

Description of the Study Area: Hawassa Industrial Zone is located $275 \mathrm{~km}$ South of Addis Ababa (the capital of Ethiopia) at an altitude of 1697-1742 m a.s.l. at $7^{\circ} 06^{\prime} \mathrm{N}$ and $38^{\circ} 48^{\prime} \mathrm{E}$. It has sub-humid climate and has bimodal rainfall distribution. The main rainy season generally extends from June to October with a mean annual rainfall of about $1150 \mathrm{~mm}$. The mean annual temperature of this area is $19.5^{\circ} \mathrm{C}$, with March and April having the highest $\left(31.5^{\circ} \mathrm{C}\right)$ and November and December having the lowest $\left(15^{\circ} \mathrm{C}\right)$ temperature (Gezahegn, 2017). Hawassa Industrial Zone has a cluster of factories such as Textile, Moha-Soft Drink and Brewery-BGI. These factories discharge untreated and/or partially-treated wastewaters (Zinabu and Zerihun, 2002) into the nearby streams called Boga and Boicha that pass through the neighboring residential area before entering into"Tikur Wuha", the only perennial river that flows into Lake Hawassa (Fig. 1). The residents of the downstream areas of the
Boicha stream use the effluent laden water for irrigation, washing and watering their cattle, especially during the dry season.

Soil Sampling Site Selection: The sampling design aimed at reveal if the contamination levels exceed a threshold of unacceptable risk, identify locations of "Hot spots" (areas having high levels of contamination) and to characterize the nature and extent of contamination in the area. The sampling site was divided into three parts based on the effluent discharge routes. Site one was the Biological Lagoon area that receives effluents from the Hawassa Textile factory after settling for a short time in the Biological Lagoon on its way downstream to Boicha stream. Site two was the Boicha stream area that is the area where effluents from Textile, Moha Soft Drink and BreweryBGI factories meet downstream and merge into Tikur Wuha River. Site three was the Reference site, located $10 \mathrm{~km}$ from the Industrial Zone towards the North around Wondo Genet. It was selected as a Reference Site or a benchmark, to compare changes taking place in the Industrial Zone. This site is assumed to be free from urban and industrial effluents and that there is relatively little influence from human activities.

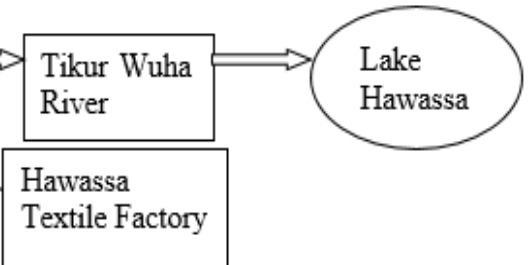

Fig 1 Routes of effluents from factories into the Lake Hawassa. Single and double arrows show the routes of effluents from factories and water from the springs to the lake, respectively.

Soil Sampling: Soil samples were collected randomly from agricultural land near the Biological Lagoon (Site one), agricultural land near the Boicha stream (Site two) and the Reference site agricultural land (Site three) using adaptive core sampling technique as described in Nybakken (1988). Ten top soil samples $(0-20 \mathrm{~cm})$ were collected from each site. Standard methods (Buckley and Cranston, 1971; Berrow and Mitchell, 1993) were used for collecting soil samples, preparation and analyses of heavy metals. The samples were sealed in polythene bags and kept in the refrigerator at $4^{\circ} \mathrm{C}$ for 5 days before being transported to Norway. The samples were air transported, in icebox filled with ice, to the Soil and Water Laboratory of the Norwegian University of Life Sciences (NMBU) for analyses of heavy metal concentrations (Cr, Ni, $\mathrm{Cu}, \mathrm{Zn}, \mathrm{As}, \mathrm{Cd}$ and $\mathrm{Pb}$ ).

Sample Preparation and Analyses for Heavy Metals: At NMBU, the soil samples were freeze-dried at app. $-50.0^{\circ} \mathrm{C}$ at $180 \mathrm{mT}$ Torr until dryness, and then screened by passing it through a sieve of $2 \mathrm{~cm}$ mesh size and crushed using pestle and mortar. Dry soil samples $(0.25 \mathrm{~g})$ were weighed into Teflon vials and $5 \mathrm{ml}$ ultrapure $\mathrm{HNO}_{3}$ was added to the vials before they were digested in an Ultraclave (Millestone) at $260^{\circ} \mathrm{C}$ for 1.5 hours. Digested soil samples were diluted with ultrapure Mill-Q water and analyzed for heavy metals using ICP-MS (Agilent 8800 QQQ). Rh, Tn and Bi were used as internal standards, and $\mathrm{O}_{2}$ gas modus was used to avoid interferences (As). According to reference material (CRM1575), the recoveries were from $90-95 \%$.

Physicochemical Properties of Soils: The organic carbon (OC) content of the soil was determined by loss on ignition (LOI) by heating the dry soil at $550.0^{\circ} \mathrm{C}$ for 4 hours (Hoogsteen et al., 2015). The cation exchange capacity (CEC) was determined by using sodium acetate and ammonium acetate solutions based on the standard published methods (Loring and Rantala, 1992). The soil $\mathrm{pH}$ was measured using a digital $\mathrm{pH}-$ 
meter (Robert and David, 2010). Soil textural properties of sand $(0.05-2 \mathrm{~mm})$, silt $(0.002-0.05 \mathrm{~mm})$, and clay $(<0.002 \mathrm{~mm})$ were measured by the hydrometer method (Andrés et al., 2014).

Table 1 Soil physicochemical properties $(\mathrm{n}=10)$ from the three sampling sites

\begin{tabular}{lllllll}
\hline Site & OM & $\mathrm{pH}$ & $\mathrm{CEC}(\mathrm{meq} / 1000 \mathrm{~g})$ & Sand $(\%)$ & Clay $(\%)$ & Silt (\%) \\
\hline Biological Lagoon area & 13.53 & 7.42 & 72.69 & 51.34 & 30.50 & 18.16 \\
Boicha stream area & 18.68 & 7.21 & 70.20 & 48.98 & 32.76 & 18.26 \\
Reference site & 12.94 & 7.10 & 65.70 & 40.84 & 38.50 & 20.66 \\
\hline \multicolumn{5}{c}{ meq = milliequivalet, CEC = cation exchange capacity, OM= organic matter }
\end{tabular}

Statistical Analyses: Data were analyzed using SPSS software version 20.0 and R studio. One way analysis of variance (ANOVA) was used to compare site wise differences in mean values of the parameters at $\alpha=0.05$ level of significance. Where significant differences were indicated, means were tested using Tukey's multiple comparisons test at $\alpha=0.05$ significance level. Pearson's correlation with statistical significance was tested at $P<0.05$ and $P<0.01$. Multivariate Statistical Approach (Principal component analysis and hierarchal cluster analysis) was performed using $\mathrm{R}$ studio for heavy metals.

Assessment of Ecological Risk of Heavy Metals in the Soils: Six assessment indices, which are explained below, were used to ascertain the potential ecological risk of heavy metals in the soils at Hawassa Industrial Zone. These include contamination factor $(\mathrm{CF})$, degree of contamination $\left(\mathrm{C}_{\mathrm{d}}\right)$, modified degree of contamination $\left(\mathrm{mC}_{\mathrm{d}}\right)$, single element potential risk factor $(E r)$, potential ecological risk index (ERI) and pollution load index (PLI).

Contamination Factor $(C F)$ : The level of contamination of soils by heavy metals suggested by Håkanson (1980) is expressed by CF. Although Håkanson has based his indices of lake sediments; his method has been developed further to soils as used by Nwankwo et al. (2019) and Danica and Juraj (2020). It is obtained from a ratio between the measured concentration of the heavy metal in soil and the preindustrial reference value for the same metal as in Equation (1):

$$
\mathrm{CF}=\frac{\mathrm{C}}{\mathrm{Cr}}
$$

Where: $\mathrm{C}$ is concentration of the metal in soil $\left(\mathrm{mg} \mathrm{kg}^{-}\right.$ $\left.{ }^{1}\right) ; \mathrm{C}_{\mathrm{r}}$ is the reference value, baseline level, or national criteria for metals.

Since there is no data on pre-industrial level of heavy metal concentrations for the study sites (no national criteria for the heavy metals in Ethiopia), concentrations of elements in the earth's crust was used as a reference value (Krzystof et al., 2004). Accordingly, the reference values are $100 \mathrm{mg} \mathrm{kg}^{-1}$ for
Cr, Ni (75), Cu (55), Zn (70), As (15), Cd (0.15) and $12.5 \mathrm{mg} \mathrm{kg}^{-1}$ for $\mathrm{Pb}$ (32). According to Håkanson (1980), the $\mathrm{CF}$ is categorized as: $\mathrm{CF}<1$, low contamination factor; $1 \leq \mathrm{CF}<3$, moderate contamination factor; $3 \leq \mathrm{CF}<6$, considerable contamination factor; and $\mathrm{CF} \geq 6$, very high contamination factor.

Degree of Contamination $\left(C_{d}\right)$ : Degree of contamination is an overall indicator of contamination based on the calculation of $\mathrm{CF}$ for each pollutant (Xu et al., 2015). It is defined as the sum of all contamination factors as in Equation (2):

$$
\mathrm{Cd}=\sum_{i=1}^{n} C F
$$

Where $\mathrm{n}=$ number of analyzed elements, $\mathrm{i}=\mathrm{i}^{\text {th }}$ element (or pollutant), $\mathrm{CF}=$ contamination factor. According to Håkanson (1980), the degree of contamination is rated as follows:

\begin{tabular}{ll}
\hline $\mathrm{C}_{\mathrm{d}}<6$ & Low degree of contamination \\
\hline $6<\mathrm{C}_{\mathrm{u}}<12$ & Moderate degree of contamination \\
$12 \leq \mathrm{C}<24$ & Considerable degree of contamination \\
\hline $\mathrm{C}_{\mathrm{l}}>24$ & Very high degree of contamination \\
\hline
\end{tabular}

Modified Degree of Contamination $\left(m C_{d}\right)$ : The $\mathrm{mC}_{\mathrm{d}}$ was introduced to estimate the overall degree of contamination at a given site ( $\mathrm{Xu}$ et al., 2015). Modified degree of contamination is defined as the sum of $C_{d}$ divided by the number of analyzed heavy metals and estimated according to Equation (3).

$$
\mathrm{mCd}=\frac{\sum_{\mathrm{i}=1}^{\mathrm{i}=\mathrm{n}} \mathrm{CF}}{\mathrm{n}}
$$

Where: $n=$ number of analyzed elements, $i=i^{\text {th }}$ element and $\mathrm{CF}=$ contamination factor. Modified degree of contamination $\left(\mathrm{mC}_{\mathrm{d}}\right)$ is rated according to Håkanson (1980) as follows:

\begin{tabular}{l|l}
\hline $\mathrm{mC}_{\mathrm{d}}<1.5$ & Very low degree of contamination \\
\hline $1.5<\mathrm{mC}_{\mathrm{d}}<2$ & Low degree of contamination \\
\hline $2<\mathrm{mC}_{d}<4$ & Moderate degree of contamination \\
\hline $4<\mathrm{mC}_{\mathrm{d}}<8$ & High degree of contamination. \\
\hline $8<\mathrm{mC}_{d}<16$ & Very high degree of contamination \\
\hline $16<\mathrm{mC}_{\mathrm{d}}<32$ & Extremely high degree of contamination \\
\hline $\mathrm{mC}_{\mathrm{d}} \geq 32$ & Ultra- high degree of contamination \\
\hline
\end{tabular}


Single Element Potential Ecological Risk Factor $\left(E_{r}\right)$ : An ecological risk factor $\left(E_{r}\right)$ is based on contamination factor of a metal and its toxic response factor. It is used to quantitatively express the potential ecological risk of a single heavy metal risk proposed by the Swedish scholar Håkanson (1980), and calculated using Equation (4).

$$
\mathrm{Er}=\operatorname{TrCF}
$$

Where $T_{r}$ is the toxic-response factor for a given substance with values for $\mathrm{Zn}=1, \mathrm{As}=10, \mathrm{Cd}=30, \mathrm{Cr}$ $=2, \mathrm{Cu}=5, \mathrm{~Pb}=5, \mathrm{Ni}=5$ according to Håkanson (1980), and $C F$ is the contamination factor of each metal. The potential ecological risks were classified on the basis of the values of the risk factor as: $E_{r}<40$, low potential ecological risk; $40<E_{r}<80$, moderate potential ecological risk; $80<E_{r}<160$, considerable potential ecological risk; $160<E_{r}<320$, high potential ecological risk; and $E_{r}>320$ very high potential ecological risks.

Potential Ecological Risk Index (ERI): Potential ecological risk index is one of the most commonly used evaluation method of metal pollution. It incorporates the concentration of heavy metals with environmental effect, toxicology, and used to assess the heavy metals pollution and ecological hazard $(\mathrm{Xu}$ et al., 2015). Potential ecological risk index is defined as the sum of all single element ecological risk factors (Håkanson, 1980) as in Equation (5):

$$
\mathrm{ERI}=\sum_{i=1}^{n} E r
$$

Table 2 Classification of potential ecological risk (Håkanson,

\begin{tabular}{|c|c|c|c|}
\hline$E$ & $\begin{array}{l}\text { Status of potential ecological } \\
\text { risk for single heavy metal }\end{array}$ & ERI & $\begin{array}{l}\text { Status of ecological } \\
\text { risk for environment }\end{array}$ \\
\hline$\overline{E<40}$ & Low & $\mathrm{ERI}<100$ & Low \\
\hline $40<E<80$ & Moderate & $100<\mathrm{ERI}<150$ & Moderate \\
\hline $80<E<160$ & Considerable & $150<\mathrm{ERI}<200$ & Considerable \\
\hline $160<E<320$ & High & $200<\mathrm{ERI}<300$ & High \\
\hline$E>320$ & Very high & $\mathrm{ERI}>300$ & Very high \\
\hline
\end{tabular}
1980):

Pollution Load Index (PLI): The pollution load index provides simple but comparative means for assessing the level of heavy metal pollution (Tomlinson et al., 1980). Each sampling site can be evaluated for the extent of the metal pollution by employing the method based on the PLI developed by Tomlinson et al. (1980) as below:

$$
\text { PLI }=(\text { CF } 1 \times \text { CF } 2 \times \text { CF } 3 \times \ldots \ldots . \times \mathrm{CF} n)_{n}^{1}
$$

Where: $\mathrm{CF}$ is the contamination factor; $\mathrm{n}$ is the number of metals studied and $\mathrm{CF}^{\mathrm{n}}$ is contamination factor for $\mathrm{n}^{\text {th }}$ element as mentioned above. According to Tomlinson et al. (1980), PLI $<1$ means that there is no indication of pollution; if it is greater than 1 , there is metal pollution.

\section{RESULTS AND DISCUSSIONS}

Levels of Heavy Metals in Soils: The mean concentration of heavy metals in the sampling sites is shown in Table 3. Mean concentrations of heavy metals in the soils generally followed the order: $\mathrm{Zn}>\mathrm{Cu}>\mathrm{Cr}>\mathrm{Ni}>\mathrm{Pb}>\mathrm{As}>\mathrm{Cd}$ from Biological Lagoon area, $\mathrm{Zn}>\mathrm{Cu}>\mathrm{Ni}>\mathrm{Cr}>\mathrm{Pb}>\mathrm{As}>\mathrm{Cd}$ from Boicha stream area and $\mathrm{Zn}>\mathrm{Cr}>\mathrm{Ni}>\mathrm{Pb}>\mathrm{Cu}>\mathrm{As}>\mathrm{Cd}$ from the Reference site. The results of the present study revealed that the concentrations of $\mathrm{Cr}$ in the soil were lower than the values reported by Fitsum and Abraha (2018) $\mathrm{Cr}\left(53.8 \mathrm{mg} \mathrm{kg}^{-1}\right)$ from Mekelle and Hintsa et al. (2016) $\mathrm{Cr}$ (40.66 $\left.\mathrm{mg} \mathrm{kg}^{-1}\right)$ from Adwa, Ethiopia. Similarly, Gebeyehu and Bayissa (2020) reported higher values of $\mathrm{Ni}\left(35.38 \mathrm{mg} \mathrm{kg}^{-1}\right)$ and $\mathrm{Pb}(37.93 \mathrm{mg}$ $\mathrm{kg}^{-1}$ ) in soils from Mojo area, Ethiopia. The mean concentrations of $\mathrm{Cd}$ in the present study were lower than the values reported by Temesgen and Seyoum (2017) $\mathrm{Cd}\left(0.98 \mathrm{mg} \mathrm{kg}^{-1}\right)$ from Koka and Danica and Juraj (2020) Cd (0.73 $\left.0.98 \mathrm{mg} \mathrm{kg}^{-1}\right)$ from Slovakia. On the contrary, our results revealed that the concentrations of other heavy metals were higher than those reported by Fitsum and Abraha (2018) Cu (20.6 $\mathrm{mg} \mathrm{kg}^{-1}$ ) from Mekelle, Temesgen and Seyoum (2017) $\mathrm{Zn}\left(67.9 \mathrm{mg} \mathrm{kg}^{-1}\right)$ from Koka. Danica and Juraj (2020), from a study in Slovakia, reported $90.07 \mathrm{mg} \mathrm{kg}^{-1}$ of As in soils. This value is extremely higher than the mean concentrations detected in soils $(8.36,6.72$ and 1.51 $\mathrm{mg} \mathrm{kg}^{-1}$ in soils from Biological Lagoon area, Boicha stream area and the Reference site, respectively) in this study. The differences could be attributed to variances in the level of anthropogenic inputs such as industrial activities, municipality wastewater discharges and the use of agrochemicals. Moreover, differences in natural sources of heavy metals such as rocks can be the reason for the differences in soil heavy metals between the studies (USEPA, 1996). The mean concentrations of $\mathrm{Cr}, \mathrm{Cu}, \mathrm{As}$ and $\mathrm{Pb}$ were higher, while the mean concentrations of $\mathrm{Ni}, \mathrm{Zn}$ and $\mathrm{Cd}$ were lower in soils from Biological Lagoon area compared to the soils from Boicha stream area (Table 3). Higher concentrations of $\mathrm{Cr}, \mathrm{Cu}, \mathrm{As}$ and $\mathrm{Pb}$ in the soils from Biological Lagoon area can be due to the discharges from Hawassa textile factory that had been using dyeing chemicals for many years according to Zinabu and Zerihun (2002). Other possible reasons for the higher concentrations of $\mathrm{Cu}, \mathrm{As}$ and $\mathrm{Pb}$ in soils from Biological Lagoon area can be the use of chemical fertilizers and pesticides in the agricultural land near the lagoon (Raymond and Felix, 2011). The higher concentration of As in the soil is likely due to the 
arsenic-containing compounds (Lead arsenate) that have been used to control pests in fruits and vegetables in the study area as noted by to Ermias et al. (2014). Higher concentrations of $\mathrm{Pb}$ in the soils from Biological Lagoon area may be due to the emission of $\mathrm{Pb}$ from discharge of motor oils, grease, fuel burning and buttery from the city since this site is closer to the city compared to the other sites. The application of livestock manures for agricultural lands is a common practice in the present study areas and it can be a possible reason for high $\mathrm{Ni}$ concentration in the soils as reported by Basta et al. (2005), in addition to the effluents from Brewery-BGI and Moha Soft Drink factories. The possible reason for higher concentration of $\mathrm{Zn}$ in the soils in the study areas can be through air deposition from nearby roads since there is busy road around the areas in addition to discharges from industries (USEPA, 1996). Reflecting lower degree of impact from pollutant activities, the mean concentrations of all heavy metals were lower in soils from the Reference site compared to their concentrations from the other two sites. This shows that the reference site is further away from anthropogenic influences (urban and industrial wastewater). There were statistically significant differences $(P<0.05)$ in the mean concentrations of $\mathrm{Cu}, \mathrm{As}, \mathrm{Cd}$ and $\mathrm{Pb}$ in soils among the study sites (Table 3). The concentrations of all heavy metals in soils sampled from all the study sites were below the maximum permissible level (MPL) for agricultural soil by FAO/WHO (2001) see Table 3 . This shows that the soils from all the study areas could be safe for agricultural activities with respect to the studied heavy metals. However, this must be cautiously interpreted as there could be uptake of heavy metals by vegetables grown on these soils, and being accumulated and transferred to other living organisms through the food chain.

Table 3 Heavy metal concentrations $\left(\mathrm{mg} \mathrm{kg}^{-1}\right)$ in the soil from the study sites (Mean $\pm \mathrm{SD}, \mathrm{n}=10$ ).

\begin{tabular}{llllllll}
\hline Site & $\mathrm{Cr}$ & $\mathrm{Ni}$ & $\mathrm{Cu}$ & $\mathrm{Zn}$ & $\mathrm{As}$ & $\mathrm{Cd}$ & $\mathrm{Pb}$ \\
\hline Biological Lagoon area & $26.10 \pm 1.02^{\mathrm{a}}$ & $13.90 \pm 0.38^{\mathrm{a}}$ & $73.30 \pm 1.12^{\mathrm{a}}$ & $133.0 \pm 5.97^{\mathrm{a}}$ & $8.36 \pm 0.23^{\mathrm{a}}$ & $0.22 \pm 0.005^{\mathrm{a}}$ & $12.90 \pm 0.38^{\mathrm{a}}$ \\
Boicha stream area & $19.70 \pm 0.47^{\mathrm{b}}$ & $21.90 \pm 1.09^{\mathrm{b}}$ & $28.72 \pm 1.0^{\mathrm{b}}$ & $140.0 \pm 3.94^{\mathrm{a}}$ & $6.72 \pm 0.24^{\mathrm{b}}$ & $0.25 \pm 0.005^{\mathrm{b}}$ & $10.93 \pm 0.40^{\mathrm{b}}$ \\
Reference site & $19.40 \pm 0.48^{\mathrm{b}}$ & $12.70 \pm 0.59^{\mathrm{a}}$ & $8.91 \pm 0.50^{\mathrm{c}}$ & $129.0 \pm 3.79^{\mathrm{a}}$ & $1.51 \pm 0.18^{\mathrm{c}}$ & $0.16 \pm 0.01^{\mathrm{c}}$ & $9.22 \pm 0.17^{\mathrm{c}}$ \\
MPL & 75.0 & 50.0 & 300.0 & 1000.0 & 20.0 & 3.0 & 50.0 \\
\hline
\end{tabular}

Mean values with different superscript letters in a column are significantly different $(P<0.05)$ from each other at $\alpha=0.05$.

$M P L=$ Maximum Permissible Limit for agricultural soils according to FAO/WHO, 2001.

Correlation between Heavy Metals in Soils: Correlation analysis was performed in order to check for the existence of correlations among heavy metals in the soils. According to Diop et al. (2015), examination of correlations provides clues on the sources of pollution, distribution and similarities of behaviors of heavy metals. The results of Pearson's correlation coefficients from this study are presented in Table 4. The analysis revealed that there were significant $(P<0.01, P<0.05)$ positive correlations between heavy metals: $\mathrm{Cr}-\mathrm{Cu} \quad(r=0.80)$, Cr-As $(r=0.59), \mathrm{Cr}-\mathrm{Pb}(r=0.61), \mathrm{Ni}-\mathrm{Zn}(r=0.41), \mathrm{Ni}-\mathrm{Cd}$ $(r=0.64)$, Cu-As $(r=0.85), \mathrm{Cu}-\mathrm{Pb}(r=0.82)$, As-Cd $(r=0.71)$, As- $\mathrm{Pb}(r=0.73)$, and Cd-Pb $(r=0.44)$. The results of the present study are similar with the findings of Elżbieta et al. (2020) who reported significant positive correlations between: $\mathrm{Cr}-\mathrm{Cu}$ $(r=0.793), \mathrm{Cr}-\mathrm{Pb}(r=0.663), \mathrm{Ni}-\mathrm{Zn}(r=0.617), \mathrm{Ni}-\mathrm{Cd}$ $(r=0.483), \mathrm{Cu}-\mathrm{Pb}(r=0.756)$ and $\mathrm{Cd}-\mathrm{Pb}(r=0.588)$ in the soils from Poland. As noted by Elżbieta et al. (2020), the correlations among the above heavy metal pairs indicate that they may have originated from common sources. Correlations between $\mathrm{Zn}$ and other heavy metals were very low, suggesting that the pollution sources of $\mathrm{Zn}$ differed from those of the other metals. This result was also supported by the results of cluster analysis revealing separate cluster of $\mathrm{Zn}$ from other heavy metals (Fig. 2). The result of the present study is different from the findings of Abu et al. (2019) who reported negative correlations between $\mathrm{Zn}-\mathrm{Cu}$, $\mathrm{Cd}-\mathrm{Cu}$, and $\mathrm{Pb}-\mathrm{Cu}$ from Bangladesh. The differences might be due to the differences in physicochemical properties of the soils between the two studies.

Table 4 Pearson's correlation matrix between heavy metal concentrations in soils from Hawassa Industrial Zone.

\begin{tabular}{rlllllll}
\hline & $\mathrm{Cr}$ & $\mathrm{Ni}$ & $\mathrm{Cu}$ & $\mathrm{Zn}$ & $\mathrm{As}$ & $\mathrm{Cd}$ & $\mathrm{Pb}$ \\
\hline $\mathrm{Cr}$ & 1 & & & & & & \\
$\mathrm{Ni}$ & -0.28 & 1 & & & & & \\
$\mathrm{Cu}$ & $0.80^{* *}$ & -0.10 & 1 & & & & \\
$\mathrm{Zn}$ & -0.08 & $0.41^{*}$ & 0.03 & 1 & & & \\
$\mathrm{As}$ & $0.59^{* *}$ & 0.30 & $0.85^{* *}$ & 0.16 & 1 & & \\
$\mathrm{Cd}$ & 0.05 & $0.64^{* *}$ & 0.36 & 0.28 & $0.71^{* *}$ & 1 & \\
$\mathrm{~Pb}$ & $0.61^{* *}$ & 0.04 & $0.82^{* *}$ & 0.14 & $0.73^{* *}$ & $0.44^{*}$ & 1 \\
$*$ Correlation is significant at the 0.01 level and *orrelation is significant at the 0.05 level
\end{tabular}

Sources of Heavy Metals: Hierarchical cluster analysis (HCA) was applied to heavy metal contents of the soil by using Euclidean distance as a measure of similarity (Fig. 2). The results indicated two main clusters: 
Cluster 1 includes (Zn) and Cluster 2 contains $(\mathrm{Cu}, \mathrm{Cr}$, $\mathrm{Cd}, \mathrm{Ni}, \mathrm{As}$ and $\mathrm{Pb})$ which is further grouped into $(\mathrm{Cu}$ and $\mathrm{Cr}$ ), and (Cd, $\mathrm{Ni}, \mathrm{As}$ and $\mathrm{Pb})$. Heavy metals such as $\mathrm{Cu}$ and $\mathrm{Cr}$ were included in the same cluster indicating similar origin. The result of the present study is consistent with the findings of Rajnees et al. (2019) who reported $\mathrm{Cr}$ and $\mathrm{Cu}$ grouped in the same cluster in soil from India. Similarly, heavy metals like $\mathrm{Cd}, \mathrm{Ni}, \mathrm{As}$ and $\mathrm{Pb}$ were included in the same cluster probably originated from the same source. Zinc alone was grouped in a separate cluster indicating the likelihood that it originated from a source different from the other heavy metals.

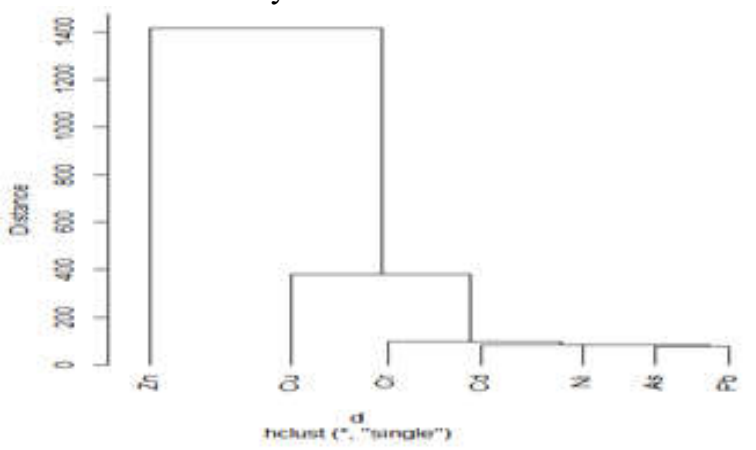

Fig 2 Cluster analyses of soil heavy metals

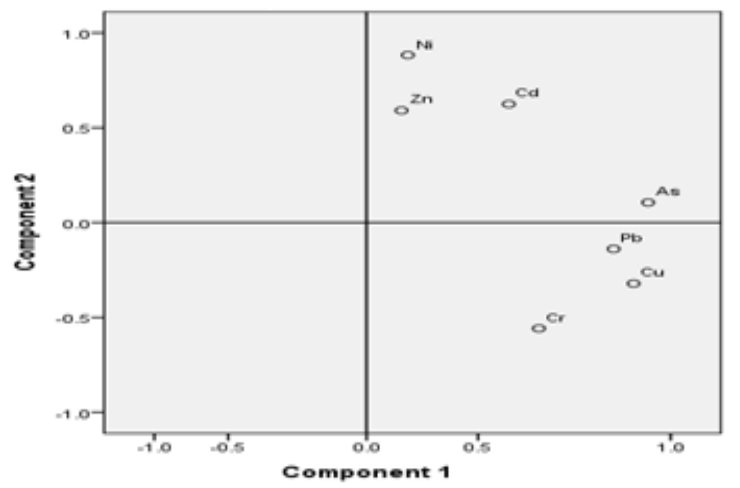

Fig 3 Component plots of soil heavy metals

The result of the principal component (PC) analysis is presented in Table 5. The first two principal components explained $78 \%$ of the total variance for soil heavy metals. PC1 had maximum loadings on As, $\mathrm{Cu}$ and $\mathrm{Pb}$, and explained $50.15 \%$ of the total variance. Natural sources like rock mineralization as well as anthropogenic sources such as industrial effluents, agrochemicals (fertilizers and pesticides) and releases from automobiles might have contributed to the high content of these heavy metals. The result of the present study is consistent with the findings of Rajnees et al. (2019) who reported maximum loading on $\mathrm{Cu}$ and $\mathrm{Pb}$ at PC1 in soil from India. PC2 had maximum loadings on $\mathrm{Ni}, \mathrm{Zn}$ and $\mathrm{Cd}$, and explained $28.06 \%$ of the total variance (Fig. 3).
Table 5 Factor loadings of heavy metals from Soil of Hawassa Industrial Zone

\begin{tabular}{lll}
\multicolumn{3}{c}{ Industrial Zone } \\
\hline Heavy metal & PC1 & PC2 \\
\hline $\mathrm{Cr}$ & 0.71 & -0.56 \\
$\mathrm{Ni}$ & 0.22 & $\mathbf{0 . 8 8}$ \\
$\mathrm{Cu}$ & $\mathbf{0 . 9 2}$ & -0.32 \\
$\mathrm{Zn}$ & 0.20 & $\mathbf{0 . 5 9}$ \\
$\mathrm{As}$ & $\mathbf{0 . 9 5}$ & 0.11 \\
$\mathrm{Cd}$ & 0.64 & $\mathbf{0 . 6 3}$ \\
$\mathrm{Pb}$ & $\mathbf{0 . 8 7}$ & -0.14 \\
\% Variance & 50.15 & 28.06 \\
\hline
\end{tabular}

Potential Ecological Risk of Heavy Metals: The Contamination Factor (CF) ranged from 2.03-4.35 for $\mathrm{Cr}, 2.13-7.30(\mathrm{Ni}), 0.44-6.11(\mathrm{Cu}), 1.22-2.80(\mathrm{Zn})$, $0.40-4.18$ (As), $1.20-2.28(\mathrm{Cd})$, and $1.08-1.84$ for $\mathrm{Pb}$ (Table 6). The CF of heavy metals was in the order: $\mathrm{Ni}>\mathrm{Cr}>\mathrm{Cu}>\mathrm{As}>\mathrm{Zn}>\mathrm{Cd}>\mathrm{Pb}$. The $\mathrm{CF}$ value of $\mathrm{Ni}$ for soil from Boicha stream area and $\mathrm{CF}$ value of $\mathrm{Cu}$ from Biological Lagoon area were greater than 6, indicating that the soils in these areas were very highly contaminated with $\mathrm{Ni}$ and $\mathrm{Cu}$ (Table 6). Danica and Juraj (2020), from a study in Slovakia, reported $C F \geq 6$ for $\mathrm{As}, \mathrm{Cd}, \mathrm{Pb}$, and $\mathrm{Zn}$, higher values than our findings. It could be attributed to iron ore mining works in the area, which do not exist in present study areas. The value of $C_{d}$ was $25.73,22.98$ and 8.50 from Biological Lagoon area, Boicha stream area and the Reference site, respectively. This reveals that soils at the Biological Lagoon area, Boicha stream area and Reference site were very highly, considerably and moderately contaminated with heavy metals, respectively (Table 6). The contamination status of the study sites by heavy metals using $\mathrm{C}_{\mathrm{d}}$ was in the order of: Biological Lagoon area $>$ Boicha stream area $>$ Reference site. The Biological Lagoon area might be exposed to heavy metal pollution from various activities such as long term industrial discharges from Hawassa textile factory, emissions from vehicles since it is near to the busy road, residential wastes and sewage effluents compared to the other two sites. The contamination status of the soils using $\mathrm{mC}_{\mathrm{d}}$ index was modified contamination in Biological Lagoon and Boicha stream areas and low contamination in the Reference site (Table 6). This shows that soils from Biological Lagoon and Boicha stream areas were more contaminated by heavy metals than the soils from the Reference site likely due to more anthropogenic influences. The single element ecological risk factor $\left(\mathrm{E}_{\mathrm{r}}\right)$ values ranged from $6.47-8.70$ for $\mathrm{Cr}$, 21.17-36.50 (Ni), 3.71-30.54 (Cu), 2.58-2.80 (Zn), 7.54-41.80 (As), 43.36-68.46 (Cd) and 6.59-9.21 for $\mathrm{Pb}$. The $E_{r}$ values of $\mathrm{As}$ and $\mathrm{Cd}$ in Biological Lagoon area, and $\mathrm{Cd}$ in Boicha stream area and the Reference site were between 40 and 80 , indicating moderate potential ecological risks. Teresiah et al. (2016) reported much lower values of $E_{r}(\mathrm{Cr}=0.01, \mathrm{Ni}=0.02, \mathrm{Cu}=0.25$, $\mathrm{Zn}=0.12, \mathrm{As}=0.61, \mathrm{Cd}=9.92$ and $\mathrm{Pb}=0.15)$ in 
agricultural soils from Kenya than the values obtained in this study. This disparity in $E_{r}$ values might be due to differences in pollution levels between the study areas. The average $E_{r}$ of heavy metals in the soil was in the order: $\mathrm{Cd}>\mathrm{As}>\mathrm{Ni}>\mathrm{Cu}>\mathrm{Pb}>\mathrm{Cr}>\mathrm{Zn}$. The ERI value was between 150 and 200 for Biological Lagoon and Boicha stream areas, indicating considerable potential ecological risks whereas it was less than 100 for the Reference site, indicating low potential ecological risks. The higher values of ERI at Biological Lagoon and Boicha stream areas might be due to the industrial and urban wastes. The PLI values were greater than unity $(>1)$ for soils from Biological Lagoon and Boicha stream areas (Table 7) revealing that the soil from these sites was polluted with heavy metals.

Table 6 Contamination factor (CF), degree of contamination $\left(\mathrm{C}_{\mathrm{d}}\right)$, modified degree of contamination and pollution load index (PLI) of heavy metals for soils from Hawassa Industrial Zone.

\begin{tabular}{|c|c|c|c|c|c|c|c|c|c|c|c|c|c|}
\hline \multirow[b]{2}{*}{ Site } & \multicolumn{7}{|c|}{ Contamination factor (CF) } & \multirow[b]{2}{*}{$\mathrm{C}_{\mathrm{d}}$} & \multirow[b]{2}{*}{ Status } & \multirow[b]{2}{*}{$\mathrm{mC}_{\mathrm{d}}$} & \multirow[b]{2}{*}{ Status } & \multirow[b]{2}{*}{ PLI } & \multirow{2}{*}{$\begin{array}{l}\text { Pollution } \\
\text { level }\end{array}$} \\
\hline & $\mathrm{Cr}$ & $\mathrm{Ni}$ & $\mathrm{Cu}$ & $\mathrm{Zn}$ & A.5 & $\mathrm{Cd}$ & $\mathrm{Pb}$ & & & & & & \\
\hline Biold & 4.35 & 4.63 & 6.11 & 2.66 & 4.18 & 1.96 & 1.84 & 25.73 & Very high & 3.68 & Moderate & 3.69 & Polluted \\
\hline Boicha stream area & 3.28 & 7.30 & 2.39 & 2.80 & 3.36 & 2.28 & 1.56 & 22.98 & Considerable & 3.28 & Moderate & 2.95 & Polluted \\
\hline
\end{tabular}

Table 7 Ecological risk factor (Er) and Potential ecological risk index (RI) of heavy metals for soils from Hawassa Industrial Zone.

\begin{tabular}{|c|c|c|c|c|c|c|c|c|c|}
\hline \multirow[b]{2}{*}{ Site } & \multicolumn{7}{|c|}{ Ecological risk factor $\left(E_{r}\right)$} & \multirow{2}{*}{$\begin{array}{l}\text { Ecological risk } \\
\text { index (ERI) }\end{array}$} & \multirow[b]{2}{*}{ Ecological risk } \\
\hline & $\mathrm{Cr}$ & $\mathrm{Ni}$ & $\mathrm{Cu}$ & $\mathrm{Zn}$ & As & $\mathrm{Cd}$ & $\mathrm{Pb}$ & & \\
\hline Biological Lagoon area & 8.70 & 23.17 & 30.54 & 2.66 & 41.80 & 58.64 & 9.21 & 174.72 & Considerable \\
\hline Boicha stream area & 6.57 & 36.50 & 11.97 & 2.80 & 33.60 & 68.46 & 7.81 & 167.69 & Considerable \\
\hline Reference site & 6.47 & 21.17 & 3.71 & 2.58 & 7.54 & 43.36 & 6.59 & 91.42 & Low \\
\hline
\end{tabular}

Conclusions: The findings of this study have revealed that the soil from Hawassa Industrial Zone is highly contaminated with heavy metals. This puts the neighboring communities into health risks through consumption of vegetables grown on such soils and hence calls for regular monitoring. The study also presents relevant information on potential ecological risk of soil in upcoming industrialized areas of developing countries. Furthermore, the study provides basic data for comparative studies with highly industrialized parts of the world.

Acknowledgements: This study was financed by the Institutional Collaboration Program between the Norwegian University of Life Sciences (NMBU) and Hawassa University, supported by the Royal Norwegian Embassy in Addis Ababa. We thank Pia Frostad for her help in the laboratory analyses of the samples.

\section{REFERENCES}

Abu, RK; Mosummath, HA; Palash, KD (2019). Assessment of heavy metals concentrations in the soil of Mongla industrial area, Bangladesh. Environ. Health Eng. Manag. 6(3):191-202.

Andrés, NB; Ana, VS; Leonardo, P; Deborah, T; Daniel, B; Raquel, M; Adriana, G (2014). Soil texture analyses using a hydrometer: modification of the Bouyoucos method. Cien. Inv. Agr. 41(2):263-271.

Basta, NT; Ryan, JA; Chaney, RL (2005). "Trace element chemistry in residual-treated soil: key concepts and metal bioavailability," J. Environ Qual. 34(1): 49-63.
Benti, F; Yonas, S; Teshome, S (2016). Assessment of the Status of Industrial Waste Water Effluent for Selected Industries in Addis Ababa, Ethiopia. J. Nat. Sci. 6(17).

Berrow, ML; Mitchell, RL (1993). Location of trace elements in soil profiles: total and extractable content of individual horizons. Trans. R. Soc. Edinburgh: Earth Science1980, 17: 103-121. In: Carter, M.R. ed. Soil sampling and methods of analysis. Canadian Society of Soil Science Lewis Publishers, Boca Raton, Ann Arbor London, Tokyo, 1993

Buckley, DE; Cranston, RE (1971). Atomic absorption analysis in 18 elements from a single decomposition of aluminosilicate. Chem. Geol. 1971, 7: 273-284. In: Carter, M.R. ed. Soil sampling and methods of analysis. Canadian Society of Soil Science Lewis Publishers, Boca Raton, Ann Arbor London, Tokyo.

Danica, F; Juraj, F (2020). Soil Quality and Heavy Metal Pollution Assessmentof Iron Ore Mines in Nizna Slana (Slovakia). Sustainability. 12: 2549.

Diop, C; Dewaelé, D; Cazier, F; Diouf, A; Ouddane, B (2015). Assessment of trace metals contamination level, bioavailability and toxicity in sediments from Dakar coast and Saint Louis estuary in Senegal, West Africa. Chemosphere.138:980-987.

Elżbieta, R; Andrzej, CŻ; Magdalena, MS (2020). Assessment of Heavy Metal Content in Soils Adjacent to the DK16-Route in Olsztyn (North-Eastern Poland). Pol. J. Environ. Stud. 29(6):4303-4311.

Ermias, D; Bjorn, OR; Reidar, B; Ole, ME (2014). Organochlorine Pesticides and Polychlorinated Biphenyls in Fish from Lake Awassa in the Ethiopian 
Rift Valley: Human Health Risks. Bull Environ Contam Toxicol. 93(2): 238-244.

FAO/WHO (2001). Codex alimentarius commission. Food additives and contaminants. Joint FAO/WHO Food Standards Programme 2001, ALINORM 10/12A.

Fawen, Z; Yulong, H; Changmin, Z; Yuanbo, K; Kai, H (2020). Heavy Metals Pollution Characteristics and Health Risk Assessment of Farmland Soils and Agricultural Products in a Mining Area of Henan Province, China. Pol. J. Environ. Stud. 29(5):39293941.

Ftsum, G; Abraha, G (2018). Health risk assessment of heavy metals via consumption of Spinach Vegetable grown in Elalla River. Bull. Chem. Soc. Ethiop. 32(1): $65-75$.

Gebeyehu, HR; Bayissa, LD (2020). Levels of heavy metals in soil and vegetables and associated health risks in Mojo area, Ethiopia. PLOS ONE 15(1): e0227883.

Gezahegn, A (2017). Long-term climate data description in Ethiopia. Data in Brief. 14: 371-392.

Håkanson, L (1980). An ecological risk index for aquatic pollution control of sediment ecological approach. Water Res. 14:975-1000

Hintsa, G; Masho, H; Mehari, M; Yirgaalem, W; Dawit, G; Desta, G (2016). Bioaccumulation of heavy metals in crop plants grown near Almeda Textile Factory, Adwa, Ethiopia. Environ Monit Assess. 188 (9): 500.

Hoogsteen, MJJ; Lantinga, EA; Bakker, EJ; Groot, JCJ; Tittonell, PA (2015).Estimating soil organic carbon through loss on ignition: effects of ignition conditions and structural water loss. Eur. J. Soil Sci. 66(2):320328.

Krzystof, L; Danuta, W; Irena, K (2004). Metal Contamination of Farming Soils Affected by Industry. Environ Int. 30(2):159-65.

Loring, DH; Rantala, RT (1992). Manual for the geochemical analyses of marine sediments and suspended particulate matter. Earth Sci Rev. 32: 235283.

Nybakken, JW (1988). Marine Biology: An ecological approach, second edition, Harper Collins Publisher. Pp. 503.
Nwankwo, RC; Tongu, SM; Eneji, IS; Nnamonu, LA; Wuana, RA; Sha'Ato, R (2019). Assessment of Potential Ecological Risk of Heavy Metals in Soils from Waste Dumpsites in Military Formations in Makurdi, Nigeria. J. Environ Pro. 10:514-531.

Raymond, AW; Felix, EO (2011). Heavy Metals in Contaminated Soils: A Review of Sources, Chemistry, Risks and Best Available Strategies for Remediation. Int Schol Res Not. 2011: 20.

Robert, OM; David, EK (2010). Comparison of Soil pH Methods on Soils of North America. Soil Sci. Soc. Am. J. 74:310-316.

Solomon, S; Yadessa, C; Girma, T; Daniel, F (2015). Heavy Metal Concentrations and Physicochemical Characteristics of Effluent along the Discharge route from Hawassa Textile Factory, Ethiopia. J Environ Anal Toxicol. 5:4.

Temesgen, E; Seyoum, L (2017). Heavy metals bioconcentration from soil to vegetables and appraisal of health risk in Koka and Wonji farms, Ethiopia. Environ Sci Pollut Res. 24:11807-11815.

Teresiah, M; Anita, A; Victorine, A; Yan, G; Xue, Y; Jun, $\mathrm{W}$ (2016). Occurrences and toxicological risk assessment of eight heavy metals in agricultural soils from Kenya, Eastern Africa. Environ Sci Pollut Res. 23:18533-18541.

Tomlinson, DC; Wilson, JG; Harris, CR; Jeffrey, DW (1980). Problems in the assessment of heavy-metal levels in estuaries and the formation of a pollution index. Helgoland Mar. Res. 33:566-575.

USEPA (1996). Report: Recent Developments for In Situ Treatment of Metals contaminated Soils, U.S. Environmental Protection Agency, Office of Solid Waste and Emergency Response.

Xu, X; Lu, X; Han, X; Zhao, N (2015). Ecological and Health Risk Assessment of Metal in Re-Suspended Particles of Urban Street Dust from an Industrial City in China. Current Science. 108:72-79.

Zinabu, GM; Zerihun, D (2002). The chemical composition of the effluent from Hawassa Textile factory and its effects on aquatic biota. SINET: Ethiop. J. Sci. 25 (2): 263-274. 